\title{
A Retrospective Study on Epidemiology of Asthma and Chronic Obstructive Pulmonary Disease
}

\author{
Janga Akhila', Sree Keerthi MV ${ }^{2}$ and Vatipelli Mahender ${ }^{1}$ \\ ${ }^{1}$ St. Peter's Institute of Pharmaceutical Sciences, Telangana, India \\ ${ }^{2}$ Vennela Chest Clinic, Telangana, India
}

\begin{abstract}
Chronic respiratory disease which majorly includes Asthma and Chronic Obstructive pulmonary disease that may account for an estimated burden of about 100 million individuals in India. There were only few studies from India on the field of epidemiology of Asthma and COPD. The prevalence rates for both disorders reported in different studies have widely varied. In phase-I of the observational study on epidemiology of Asthma and COPD was conducted at a chest clinic. Population prevalence of Asthma and COPD in all age groups was reported and analyzed. In phase-II of observational study a standardized and validated questionnaire was used employing auniform methodology in all patients. The main objective of this project is to find differences in the epidemiology of asthma and chronic obstructive pulmonary disease, including in the prevalence rates and other casual variables (age, gender, residence, occupation), if any, in different places in a Chest Clinic. And also to assess the influence of exposure to tobacco smoking, ETS (Environmental tobacco smoke) and other risk factors, on the prevalence of both Asthma and COPD.
\end{abstract}

Keywords: Asthma; Chronic obstructive pulmonary disease; Risk factors; Epidemiology

Abbreviations: COPD: Chronic Obstructive Pulmonary Disease; ETS: Environmental Tobacco Smoke; PMHx: Past Medical History; FHx: Family history; SHx: Social History

\section{Introduction}

India is a country with vast economical, racial and religious differences. Chronic respiratory disease includes majorly Asthma and COPD. These diseases account for 100 million individuals in India. Both are the inflammatory disorders of airways.

\section{Asthma}

Asthma is a chronic inflammatory disorder characterized by airway hyper-responsiveness to a variety of stimuli. It results from a complex interaction among inflammatory cells, mediators and airways. For practical purposes, asthma may be defined as a disorder of the airways characterized by the following:

- Paroxysmal and/or persistent symptoms such as dyspnea, chest tightness, wheezing and cough, with or without mucus production.

- Variable airflow limitation demonstrated by chest auscultation and/or repeated measurements of peak expiratory flow (PEF) or other spirometric indices.

- Airway hyper-responsiveness to a variety of specific and nonspecific inhalational stimuli.

Severity of obstruction is variable and believed to be as a result of bronchoconstriction airway wall edema, mucus plug formation [1]. It reduces the ventilation to some lung regions which causes a perfusion imbalance that leads to hypoxemia. According to 2001 census, in India prevalence of Asthma is 2.03\% -men, 1.87\%-women total 1.95\% [1].

\section{COPD}

Chronic obstructive pulmonary disease is also an inflammatory disorder of the airways which is a major cause of disability and death all over the world, including in India. Unlike asthma, COPD is primarily a disease of adults and runs a progressive downhill course [2]. It includes the clinical conditions of chronic bronchitis and emphysema where chronic bronchitis is defined as the presence of cough and mucous expectoration for at least 3 months in a year continuously for two or more years and Emphysema is a clinical condition causing permanent damage to the alveoli. In this respiratory tissue inflammation occurs which results in vasodilation, congestion, mucosal edema, goblet cell hypertrophy. These events trigger goblet cells to produce excess amount of mucous. In severe condition, clusters of alveoli merge further leading to diminishing the number of alveoli finally resulting in increased space available for air trapping. According to 2001 census in India, prevalence of COPD observed as men- $4.18 \%$, women- $2.74 \%$ and total-3.48\% [1].

Due to no particular differentiation of asthma and COPD symptoms, the prevalence rates greatly vary in different conditions and different studies.

This variation may also due to place of residence, socio-economic status. Smoking and tobacco chewing also shows significant difference. Thus epidemiological studies are required to assess the respiratory burden of particular area with respective to the exposure history and risk factors. This study was carried out in a district named Jagityal, with a geographical area of $3,043.23 \mathrm{~km}^{2}$ and a population of $1,03,930$ (2001 census). It is located in Telangana state, India. The population of this district consists predominantly of backward classes and people belonging to the lower rung of the social ladder. Agriculture and beedi workers are the two main occupations of this region which are found to be main reasons for the progression of diseases asthma and COPD.

\section{Aim and Objective of the Study}

\section{Aim}

To study the epidemiology of both the diseases that includes Asthma and Chronic Obstructive Pulmonary Disease.

${ }^{*}$ Corresponding author: Vatipelli Mahender, Professor, St. Peter's Institute of Pharmaceutical Sciences, Hanamkonda, Warangal-506001, Telangana, India, Tel: +918702567303; E-mail: mahendra.v@stpeters.in

Received January 08, 2017; Accepted August 03, 2017; Published August 07 2017

Citation: Akhila J, Sree Keerthi MV, Mahender V (2017) A Retrospective Study on Epidemiology of Asthma and Chronic Obstructive Pulmonary Disease. J Pulm Respir Med 7: 418. doi: 10.4172/2161-105X.1000418

Copyright: ( 2017 Akhila J, et al. This is an open-access article distributed under the terms of the Creative Commons Attribution License, which permits unrestricted use, distribution, and reproduction in any medium, provided the original author and source are credited. 


\section{Objective}

- To find out the differences in the epidemiological aspects of asthma and chronic obstructive pulmonary disease including the prevalence rates and other casual variables (age, gender, residence, occupation) in different places of study site.

- To assess the influence of exposure to tobacco smoking, ETS (Environmental tobacco smoke) and other risk factors on the prevalence of both Asthma and COPD.

\section{Methodology}

\section{Study site}

The proposed study was carried out at Vennela Chest Clinic, Jagityal. During the study period; a total number of 175 patients were enrolled into the study. Out of them, 60 asthma patients and 50 COPD patients were considered. Vennela Hospital is a secondary health care hospital setup in Jagityal dist. This was the private center with the aim to provide effective service to the people of Jagityal and surrounding areas. Pulmonology is the major department. It provides all the facilities along with the adequate laboratory needs (it is equipped with facilities for spirometry, bronchoscope, Respiratory critical care unit and emergency requirements)

\section{Study design}

A retrospective observational study: A retrospective observational study looks backwards and examines exposures to suspected risk or protection factors in relation to an outcome that is established at the start of the study, to determine how these factors affects the rates of a certain outcome [2].

Study period: The Study period is 45 days (May 2016-June 2016)

\section{Study inclusion criteria:}

- Patients who are diagnosed with asthma and chronic obstructive pulmonary disease.

- Symptoms and family history showing evidence of both the diseases.

- Patients of either sex.

- All age groups (mostly from 0 years- 85 years).

\section{Study exclusion criteria:}

- Patients with serious life threatening conditions.

- Patients with Tuberculosis.

- Patients with uncontrolled infections.

Study materials:All the relevant and necessary data was collected in the data collection form which includes Interviewing patients or patient care takers, health care professionals, prescriptions, patient case sheet and any other relevant sources [3].

The data collected include: Demographic details, chief complaints, past medical history, past medication history, family history, social history, general examination, information about sensitivity towards occupational and environmental triggering factors, social habits like smoking and tobacco usage, diagnosis and Medication chart [4].

Study procedure:Patients visiting Vennela chest clinic were reviewed on a daily basis. The patients who met the study criteria were enrolled into the study and the following information was collected: patient demographics, chief complaints, $\mathrm{PMHx}, \mathrm{FHx}, \mathrm{SHx}$, sensitivity towards occupational and environmental factors, smoking and tobacco usage and current medication. The patients with positive diagnosis towards asthma and chronic obstructive pulmonary disease were included. The data collected manually was reviewed and entered into Microsoft Excel database and then analyzed statistically.

\section{Results}

The roles of several factors were assessed in the study to help clinicians in decision making.

\section{Gender}

The percentage of allergy is greater in women than in men. In this study, the significant occurrence of Asthma and COPD was strongly associated with female population with $(\mathrm{P}=0.58)$ and the percentage of female population are higher when compared to males with frequencies of $64(58 \%)$ and $46(42 \%)$ respectively. The ratio of females- males $(\mathrm{F} / \mathrm{M})$ is $1.38: 1$. The $\mathrm{p}$ values of males was found to $\mathrm{be} \mathrm{P}=0.316$ in and $\mathrm{P}=0.68$ in females in Asthma, whereas in COPD $\mathrm{P}=0.540$ in males and $\mathrm{P}=0.460$ in females (Table 1 ).

\section{Age}

Asthma is more among the individuals of young age 10-25 years, were as COPD was more between the age group of 60-70 years. Study population, the percentage of asthma is higher in the age group of 0-25 years (40\%), followed by 26-40 years (33.3\%), 41-60 years (21.66\%), 61 and above (5\%), and among COPD higher number of patients were in age group of $61-70$ years (38\%), 51-60 years (24\%), then $40-50$ years (20\%), 71-80 years (12\%) 81 and above (4\%), 35-40 years (2\%) age groups patients (Table 2).

\section{Other risk factors (smoking and tobacco chewing)}

Significant occurrence of Asthma and COPD was found in relation with the risk factor tobacco chewing, predominantly in females [5].

Male patients (5\%) diagnosed with asthma who having habit of smoking, were as male patients (38\%) with COPD were smokers. In tobacco chewing in asthma $(\mathrm{n}=7)$ patients $(11.66 \%)$ were observed, among them $(n=2)$ male patients $3.33 \%)$ female patients $(n=5) 8.33 \%$ and in COPD $(\mathrm{n}=22)$ patients $44 \%$ were observed, among them male patients $(n=5) 10 \%$ and female patients $(n=17) 34 \%$ were observed [6]. The $\mathrm{p}$ value of COPD for smoking was found to be 0.380 in males and $\mathrm{p}=0.440$ in females in case of tobacco chewing and it is the predominant (Table 3).

\begin{tabular}{|c|c|c|c|}
\hline Gender & Total & Asthma & COPD \\
\hline Male & $42 \%$ & $31 \%$ & $54 \%$ \\
\hline Female & $58 \%$ & $68.33 \%$ & $46 \%$ \\
\hline
\end{tabular}

Table 1: Gender wise distribution.

\begin{tabular}{|c|c|}
\hline AGE (IN YEARS) & PERCENTAGE \\
\hline $0-25$ & $42 \%$ \\
\hline $26-40$ & $32 \%$ \\
\hline $35-40$ & $2 \%$ \\
\hline $40-50$ & $20 \%$ \\
\hline $41-60$ & $22 \%$ \\
\hline $51-60$ & $24 \%$ \\
\hline $61-70$ & $38 \%$ \\
\hline $71-80$ & $12 \%$ \\
\hline 61 and above & $4 \%$ \\
\hline 81 and above & $4 \%$ \\
\hline
\end{tabular}

Table 2: Age wise distribution. 
Citation: Akhila J, Sree Keerthi MV, Mahender V (2017) A Retrospective Study on Epidemiology of Asthma and Chronic Obstructive Pulmonary Disease. J Pulm Respir Med 7: 418. doi: 10.4172/2161-105X.1000418

Page 3 of 3

\begin{tabular}{|c|c|c|c|c|c|c|}
\hline & \multicolumn{3}{|c|}{ ASTHMA } & \multicolumn{3}{|c|}{ COPD } \\
\hline & TOTAL & MALE & FEMALE & TOTAL & MALE & FEMALE \\
\hline Smoking history & $5 \%$ & $5 \%$ & - & $38 \%$ & $38 \%$ & - \\
\hline Tobacco chewing & $11.66 \%$ & $3.33 \%$ & $8.33 \%$ & $44 \%$ & $10 \%$ & $34 \%$ \\
\hline
\end{tabular}

Table 3: Occurrence of asthma and COPD in relation with smoking and tobacco chewing

\begin{tabular}{|c|c|}
\hline Total & $25 \%$ \\
\hline Male & $10 \%$ \\
\hline Female & $15 \%$ \\
\hline
\end{tabular}

Table 4: Assessment of family history.

\begin{tabular}{|c|c|c|}
\hline Occupation & Asthma & COPD \\
\hline Beedi worker & $20 \%$ & $8 \%$ \\
\hline Farmer & $21.66 \%$ & $68 \%$ \\
\hline Unskilled worker & $16.66 \%$ & $22 \%$ \\
\hline House wife & $10 \%$ & $2 \%$ \\
\hline Student & $26.66 \%$ & - \\
\hline Others & $5 \%$ & - \\
\hline
\end{tabular}

Table 5: Assessment of occupation.

\section{Family history}

The family history of the Asthma patients was taken during the patient interview. In this study population, family history of asthma was found to be significant with current asthmatic patients and it was found to be $25 \%(n=15$ and $P=0.240)$. There is no evidence of genetic predisposition in COPD patients (Table 4 ).

\section{Occupation}

In both the diseases asthma and COPD, farmers occupy a major number of total populations followed by beedi workers. More number of students also observed in case of asthma (Table 5) [7].

\section{Discussion}

Epidemiology is the study of the occurrence, distribution and determinants of health conditions in populations, and the application of this knowledge to control health problems. It is fundamental to improving public health. Chronic respiratory disease which includes Asthma and Chronic Obstructive pulmonary disease, may account for an estimated burden India [8]. There were only few studies from India on the field of epidemiology of Asthma and COPD. The prevalence rates for both disorders reported in different studies have widely varied. According to 2001 census, in India prevalence of Asthma is $2.03 \%$-men, $1.87 \%$ - women, total $1.95 \%$, whereas for COPD men$4.18 \%$,women- $2.74 \%$,total-3.48\%. Based on the study ,it was found that, the prevalence rate of Asthma was found to be $0.35 \%$ and COPD of $0.27 \%$ (approximately). In this study, the percentage of female population was higher when compared to males [9]. The percentage of asthma is higher in the age group of 10-25 years which indicates the genetic predisposition, and among COPD higher number of patients were in age group of 61-70 years, as COPD is a chronic disease and is progressed as age increases [10]. Among asthma patients $75 \%$ were allergic to occupational and environmental triggers, were as in COPD $74 \%$ were allergic as most of the population are beedi workers and farmers which are the main risk factors. Among COPD 38\% were smokers [11].

The tobacco chewing was found to be $44 \%$ in COPD. Family history of asthma was found to be more, and it is observed to have $25 \%$ of total asthma patients. There is no evidence of genetic predisposition in COPD patients. In the study population in both the diseases asthma and COPD farmers occupy a major number of total populations followed by beedi workers. More number of students is also observed in case of asthma [12].

\section{Conclusion}

The strong environmental and occupational triggering factor that contributes for the development of COPD was observed with air pollution.

Genetic predisposition plays a major risk factor causing Asthma in addition to air pollution Apart from these risk factors, occupation contributes to the progression of disease. Its alarming time to bring out significant monitoring in the respiratory disease prone areas considering their risk factors and exposure history. Different patient counseling strategies should be adopted in such areas and awareness among the population considering the risk factors and triggers that could have a strong significant relation with Asthma and COPD.

This plays a vital role in decreasing the prevalence and incidence rates. Further understanding of risk factors in relation to pathophysiology could improve management in this vulnerable population.

\section{Acknowledgment}

I am grateful to Dr. Suresh Bandari for his support throughout this work.

\section{References}

1. Icmr.in/final/INSEARCH.full\%_Report.pdf

2. Tortora GJ, Derrickson BH (2008) Principles of anatomy and physiology $\left(12^{\text {th }}\right.$ edition) John Wiley \& Sons Inc., New Jersey, United States.

3. Davidson (2014) Principles and practice of Medicine. Walker BR, Colledge NR, Ralston SH, Penman I (Editors) Elsevier Science Publishers, Amsterdam, Netherlands.

4. Kimble MAK, Alldredge BK (2013) Applied Therapeutics : The clinical use of drugs. Wolters Kluwer publishers, Philadelphia, USA.

5. Brunton L, Blumenthal D, Buxton I, Parker K (2008) Goodman \& Gilman's Manual of Pharmacology and Therapeutics. McGraw Hill professional, New York, USA.

6. Harshmohan (2010) Text book of pathology ( $7^{\text {th }}$ edition).

7. Gibson PG, Simpson JL (2009) The overlap syndrome of asthma and COPD What are its features and how important is it?. Thorax 64: 728-735.

8. Coultas D (1998) Passive smoking and risk of adult asthma and COPD: an update. 53: 381-387.

9. Kauppi P, Kupiainen H, Lindqvist A, Tammilehto L, Kilpeläinen M, et al. (2011) Overlap Syndrome of asthma and copd predicts low quality of life. J Asthma 48: 279-285.

10. Traulsen LK, Baelum J, Halling A, Trine T, David S, et al. (2015) Risk factors for new-onset asthma and early COPD in a cohort of young adults. Eur Respir J 46: 1118-1122.

11. www.Census2011.co.in

12. Kasper DL, Braunwald E, Fauci AS, Hauser SL, Longo DL, et al. (2005) HARRISON'S priciples of internal medicine by Harrison ( $16^{\text {th }}$ edition). McGrawHill Medical, Pennsylvania, USA. 